\title{
PERILAKU TIM DAN BADAN ANGGARAN DALAM FORMULASI KEBIJAKAN UMUM ANGGARAN
}

\author{
Bima Sujendara, Ngusmanto \\ Fakultas Ilmu Sosial dan Ilmu Politik Universitas Tanjungpura
}

\begin{abstract}
Abstrak: Perilaku Tim dan Badan Anggaran Dalam Formulasi Kebijakan Umum Anggaran Kota Pontianak, dari waktu ke waktu dilatar belakangi oleh fenomena adanya keterlambatan yang terus menerus terjadi. Untuk itu, peneliti bertanya: "Mengapa formulasi Kebijakan Umum Anggaran yang dilakukan tim anggaran dan badan anggaran mengalami keterlambatan ?". Pertanyaan ini akan dijelaskan melalui teori perilaku birokrasi. Hasil penelitian menunjukkan bahwa Keterlambatan formulasi Kebijakan Umum Anggaran (KUA) terjadi karena perilaku tim dan badan anggaran kurang bertanggung jawab. Tanggung jawab yang kurang terlihat dari penyerahan draf KUA dan pengesahan dokumen KUA yang terlambat, kehadiran tim perumus yang kurang dalam proses pembahasan formulasi KUA dan tidak dipatuhinya jadual pembahasan formulasi KUA. Di sisi lain, keterlambatan yang terjadi karena ada unsur kesengajaan dan dimotivasi untuk mendapatkan keuntungan materi dan non materi.
\end{abstract}

Kata Kunci: Perilaku, Formulasi, Kebijakan, Anggaran dan Tanggung Jawab

Formulasi kebijakan umum Anggaran Pendapatan (yang selanjutnya disingkat KUA) harus diselesaikan tepat waktu. Tuntutan demikian logis karena dokumen ini menjadi dasar penyusunan Prioritas Plafon Anggaran Sementara (PPAS) dan Rencana Anggaran Pendapatan Dan Belanja Daerah (RAPBD), sekaligus berpengaruh terhadap upaya meningkatkan kesejahteraan masyarakat, yang secara legal formal menjadi tugas pokok, kewenangan dan dipercayakan kepada pemerintah kota (eksekutif) melalui Tim Anggaran Pemerintah Kota dan wakil rakyat yang duduk di Dewan Perwakilan Rakyat Daerah (DPRD) atau legislatif melalui Badan Anggaran DPRD kota Pontianak, dengan dukungan birokrasi pemerintah. Dalam proses formulasi KUA sampai dengan pengesahan menjadi dokumen KUA memiliki 3 (tiga) tahapan dan masing-masing tahapan memiliki proses yang saling terkait sebagai satu kesatuan. Tahapan tersebut dimulai dari proses penyiapan draf KUA. Penyiapan draf dilaksanakan oleh tim anggaran melalui ketua Badan Perencanaan Pembangunan Daerah (Bappeda), dengan dukungan birokrasi Bappeda. Dalam tahap ini terjadi interaksi antar anggota tim anggaran dan dibantu oleh tenaga ahli dari Universitas Tanjungpura (Untan) di bawah kendali dan pengarahan walikota Pontianak. Selesai penyiapan draf KUA, dilanjutkan penyerahan draf KUA kepada DPRD oleh walikota untuk dilakukan pembahasan bersama antara tim anggaran dengan badan anggaran DPRD. Dalam proses ini terjadi interaksi antara tim anggaran dengan badan anggaran. Dalam proses pembahasan KUA di internal badan anggaran maupun antara tim anggaran dengan badan anggaran mengalami keterlambatan, sehingga pengesahan KUA menjadi dokumen KUA yang ditandatangani walikota bersama ketua dan wakil ketua DPRD juga mengalami keterlambatan.

Fenomena keterlambatan dalam hal ini mengambil sampel keterlambatan formulasi tahun 2010 dan 2011, dengan cara membandingkan antara harapan (peraturan) dengan kenyataan (pengesahan dokumen). Peraturan Pemerintah (PP) Republik Indonesia Nomor 58 Tahun 2005 Tentang Pengelolaan Keuangan Daerah Bagian Kedua Kebijakan Umum APBD Pasal 34 ayat (3) diamanahkan bahwa: Kepala daerah menyampaikan rancangan kebijakan umum APBD tahun anggaran berikutnya sebagaimana dimaksud pada ayat (2) sebagai landasan penyusunan RAPBD kepada DPRD selambat-lambatnya pertengahan bulan Juni tahun anggaran berjalan.

Selanjutnya, peraturan Menteri Dalam Negeri Nomor 13 Tahun 2006 Tentang Pedoman Pengelolaan Keuangan Daerah Bagian Ketiga Kebijakan Umum ABBD serta Prioritas dan Plafon Anggaran Sementara Pasal 86 ayat (3) diamanahkan bahwa "Rancangan KUA yang telah dibahas sebagaimana dimaksud pada ayat (2) selanjutnya disepakati menjadi KUA paling lambat minggu pertama bulan Juli Tahun anggaran berjalan". Data tentang keterlambatan formulasi KUA mulai dari persiapan, pembahasan dan pengesahannya, secara rinci disajikan pada Tabel 1. Fenomena keterlambatan seperti yang disajikan pada Tabel 1.1 terlihat dengan jelas dari tanggal dan bulan waktu penyerahan Rancangan KUA. Penyerahan draf KUA Tahun 2010 dari Pemerintah Kota Pontianak Kepada DPRD dilakukan pada 
tanggal 10 September 2009 dan draf tahun 2011 baru diserahkan pada tanggal 28 Juni 2010 (harusnya pertengahan bulan Juni setiap tahun), sedangkan pengesahan KUA tahun 2010 ditetapkan pada tanggal 9 Nopember 2009 dan pengesahan KUA tahun 2011 ditetapkan pada tanggal 30 Agustus 2010 (harusnya awal bulan Juli setiap tahun). Jadi, keterlambatan proses formulasi KUA Kota Pontianak dimulai dari persiapan dan penyerahan draf KUA kepada DPRD serta proses pembahasan antara tim anggaran dengan badan anggaran dan pengesahannya. Untuk mengkaji fenomena keterlambatan tersebut, peneliti akan menelusuri perilaku tim anggaran dan badan anggaran dari aspek tanggung jawab mereka dalam pelaksanaan tugas pokok, khususnya dalam formulasi KUA serta menelusuri motivasi-motivasi yang berkembang dibalik fenomena keterlamatan dalam proses formulasi KUA dari teori perilaku birokrasi. Untuk itu, permasalahan umum penelitian dirumuskan: "Mengapa formulasi Kebijakan Umum Anggaran Kota Pontianak mengalami keterlambatan?".

Tabel 1

Proses Formulasi Kebijakan Umum Anggaran Kota Pontianak Tahun 2010 dan 2011 Berdasarkan Perspektif Waktu

\begin{tabular}{|c|c|c|c|c|}
\hline No & Uraian & $\begin{array}{c}\text { Tanggal, } \\
\text { Bulan dan } \\
\text { Tahun } 2009\end{array}$ & $\begin{array}{c}\text { Tanggal, Bulan dan } \\
\text { Tahun } 2010\end{array}$ & $\begin{array}{c}\text { Tanggal dan } \\
\text { Bulan } \\
\text { Menurut } \\
\text { Peraturan }\end{array}$ \\
\hline 1 & \begin{tabular}{lr}
\multicolumn{2}{l}{ Penyerahan } \\
Rangcangan \\
KUA Tahun 2010 \\
dari Pemerintah \\
Kota r Kepada \\
DPRD & \\
\end{tabular} & $\begin{array}{l}10 \text { September } \\
2009\end{array}$ & 28 Juni 2010 & $\begin{array}{l}\text { Selambat- } \\
\text { Lambatnya } \\
\text { Pertengahan } \\
\text { Bulan Juni }\end{array}$ \\
\hline 2 & \begin{tabular}{lr}
\multicolumn{2}{l}{ Pembahasan } \\
Rangcangan \\
KUA Tahun 2010 \\
di tingkat Komisi, \\
Internal & Badan \\
Anggaran & DPRD \\
serta & Badan \\
Anggaran & DPRD \\
dengan & Tim \\
Anggaran & \\
Pemerintah Kota
\end{tabular} & $\begin{array}{l}\text { 2-6 Nopember } \\
2009\end{array}$ & $\begin{array}{ll}\text { a. } & 19 \text { Juli } 2010 \\
\text { Pembahasan di } \\
\text { Komisi } \\
\text { b. } 19-20 \text { Agustus } \\
2010 \\
\text { Pembahasan } \\
\text { Gabungan } \\
\text { Komisi A, B, C } \\
\text { dan D } \\
\text { 23 Agustus } \\
\text { 2010 Rapat } \\
\text { gabungan } \\
\text { badan anggaran } \\
\text { dan Komisi A, } \\
\text { B, C dan D } \\
\text { 24 - 26 } \\
\text { Agustus } 2010 \\
\text { Rapat kerja } \\
\text { Badan } \\
\text { Anggaran } \\
\text { DPRD bersama } \\
\text { Tim anggaran } \\
\text { eksekutif }\end{array}$ & \\
\hline 3 & $\begin{array}{l}\text { Penandatanganan } \\
\text { Nota Kesepakatan } \\
\text { KUA antara } \\
\text { Walikota Dengan } \\
\text { Ketua dan Wakil } \\
\text { Ketua DPRD }\end{array}$ & $\begin{array}{l}9 \text { Nopember } \\
2009\end{array}$ & 30 Agustus 2010 & $\begin{array}{l}\text { Selambat- } \\
\text { lambatnya } \\
\text { Pertengah } \\
\text { Bulan Juli }\end{array}$ \\
\hline
\end{tabular}

Sumber: Dokumen Risalah Rapat Paripurna Ke 8 Masa Persidangan Ke I DPRD Kota Pontianak 9 Nopember 2009 dan Dokumen Jadual Rapat/Kegiatan DPRD Kota Pontianak dan Risalah Rapat Paripurna Ke 17 Masa Persidangan Ke II DPRD Kota Pontianak, 30 Agustus 2010 
Permasalahan umum tersebut, selanjutnya dijabarkan ke dalam beberapa pertanyaan penelitian: (1) Mengapa formulasi KUA sebagai tugas pokok tim anggaran pemerintah kota dan badan anggaran DPRD kota Pontianak mengalami keterlambatan, yang terlihat dari penyerahan rancangan KUA dan pengesahannya, (2) Adakah faktor kesengajaan yang dilakukan oleh tim dan badan anggaran dikaji dari perspektif teori perilaku birokrasi, (3) Adakah yang salah dalam perilaku kedua lembaga dalam formulasi KUA tersebut menurut perspektif perilaku birokrasi dalam formulasi KUA, yang terkait langsung dengan pelaksanaan tugas pokok kedua lembaga tersebut, khususnya yang dilaksanakan oleh tim anggaran pemerintah dan badan anggaran DPRD, dan (4) Apakah Tim formulator tersebut memiliki motivasi-motivasi atau agenda-agenda tertentu atau tersembunyi dibalik perilaku mereka yang menimbulkan keterlambatan tersebut. Beberapa permasalahan yang telah diungkapkan, oleh peneliti akan dijelaskan dengan beberapa teori perilaku birokrasi dan formulasi kebijakan. Saefullah (2009: 37) menegaskan bahwa "perumusan kebijakan publik memfokuskan studinya pada bagaimana kebijakan itu dibuat sampai dengan keluarnya suatu ketetapan keputusan". Selanjutnya hasil penelusuran Winarno (2007: 120 - 122) tentang tahap-tahap dalam proses perumusan kebijakan terdiri dari: "Tahap Pertama: Perumusan masalah (defining problem), Tahap Kedua, Agenda kebijakan, Tahap ketiga, pemilihan alternatif kebijakan untuk memecahkan masalah dan Tahap keempat, Tahap Penetapan Kebijakan".

Beberapa tahapan dalam proses kebijakan tersebut dijelaskan lebih rinci oleh Winarno. Tahap Pertama: Perumusan masalah (defining problem). Dalam tahap ini untuk mengenali dan merumuskan masalah publik yang ada di masyarakat. Dalam langkah ini, dipertanyakan seberapa besar kontribusi kebijakan publik dapat menyelesaikan masalah-masalah dalam masyarakat. Tahap Kedua, agenda kebijakan yang menekankan bahwa tidak semua masalah publik akan masuk ke dalam agenda kebijakan. Masalah-masalah tersebut dalam realitas akan saling berkompetisi antara satu dengan yang lainnya. Hanya masalah-masalah tertentu yang akhirnya akan masuk ke dalam agenda kebijakan. Masalah yang bisa menjadi agenda kebijakan memiliki persyaratan antara lain masalah tersebut memiliki dampak yang besar dan membutuhkan penanganan segera. Masalah ini akan dibahas oleh para perumus kebijakan, khususnya eksekutif dan legislatif. Tahap ketiga, pemilihan alternatif kebijakan untuk memecahkan masalah. Setelah masalah publik didefinisikan dengan baik oleh para perumus kebijakan dan mereka sepakat untuk memasukkan ke dalam agenda kebijakan. Untuk itu, langkah selanjutnya adalah membuat pemecahan masalah. Di sini para perumus kebijakan akan berhadapan dengan alternatifalternatif pilihan kebijakan yang dapat diambil untuk memecahkan masakah tersebut. Dalam tahap ini, para perumus kebijakan akan dihadapkan pada pertarungan kepentingan antar berbagai aktor yang terlibat, sedangkan tahap keempat adalah Tahap Penetapan Kebijakan. Dalam tahap ini adalah tahap pemilihan salah satu dari sekian alternatif kebijakan untuk diputusan atau ditetapkan sebagai kebijakan yang dipilih, sehingga kebijakan tersebut memiliki legalitas atau kekuatan hukum. Alternatif kebijakan yang diambil pada dasarnya merupakan kompromi dari berbagai kelompok kepentingan yang terlibat dalam pembentukan kebijakan tersebut. Penetapan kebijakan bisa dalam bentuk UU atau peraturan lainnya.

Wahab (2008:45) menegaskan bahwa: Kebijakan mencakup perilaku dan harapanharapan. Suatu telaah kebijakan tidak boleh mengabaikan perilaku dari mereka yang merumuskan kebijakan. Dalam analisis perilaku penyusun kebijakan perlu memahami apa yang sebenarnya diharapkan oleh pembuat kebijakan, bagaimana pernyataan-pernyataan di depan publik dan apakah perilaku yang senyatanya sesuai dengan harapan-harapan si pembuat kebijakan. Jadi, peran aktor penyusunan kebijakan dapat dikaji dan diamati melalui interaksi atau hubungan antar aktor utama tim anggaran pemerintah dan badan anggaran DPRD. Interaksi antar mereka akan terjadi di internal eksekutif (antar anggota tim anggaran), sedangkan anggota dewan akan berinterkasi dengan anggota dewan kota Pontianak (Antar anggota badan anggaran) dan akhirnya akan terjadi interaksi antar kedua lembaga (tim anggaran dan badan anggaran). Sebagai individu (aktor), baik dari unsur eksekutif dan pejabat birokrasi, maupun anggota legislatif sudah pasti memiliki tujuan, motif, kebutuhan, kepentingan dan keinginan atau harapan pribadi yang harus dapat diwujudkan atau diakomodasi dalam formulasi KUA yang telah mereka tetapkan. Semua ini akan mereka perjuangan secara maksimal, dengan target hasil yang maksimal pula. Dalam perjuangan ini, mereka bisa dapat keuntungan secara finansial (keuangan) yang dilegalkan atau tidak legal melalui korupsi dan non finansial seperti kewenangan mengatur, memiliki kekuasaan dan akses yang luas.

Hal penting dan perlu mendapat perhatian yang terkait dengan proses formulasi KUA adalah ongkos jabatan, sehingga fenomena ini yang menyebabkan terjadinya rent seeking. Andi Irawan http://antikorupsi.org/indo/content/view/ 13251/7/ menegaskan bahwa; Mengapa perilaku rent seeking itu begitu mudah hadir dalam institusi negara (eksekutif, legislatif, dan yudikatif). Hal ini terjadi karena proses dan mekanisme politik yang menyebabkan seseorang hadir menjadi pejabat 
publik pada institusi-institusi negara tersebut sarat dengan transaction cost yang tinggi. Oleh karena itu, ketika sang tokoh itu menjadi pejabat publik, yang bersangkutan pasti akan menjadikan jabatannya dengan motif privat. Jabatannya itu bukan hanya digunakan untuk menutup biaya politik yang telah dikeluarkan, tetapi juga digunakan untuk mendapatkan keuntungan pribadi yang sebesarbesarnya.

Perkembangan yang dewasa ini muncul adalah semua tidak gratis, tidak mudah dan menjadi mahal. Sebagai konsekuensi, banyak orang yang harus mencari tambahan, melalui berbagai cara. Dwiyanto (2006:384) menegaskan bahwa: Besaran anggaran birokrasi ditentukan oleh para pejabat politik, menjadikan para pejabat birokrasi lebih sering memperhatikan kepentingan para pejabat politik daripada kepentingan publik. Semakin besar anggaran, semakin menguntungkan mereka dalam hubungannya dengan kepentingan birokrasi dan pejabatnya. Hal ini bermakna bahwa tidak mudah memformulasikan kebijakan publik. Saefullah (2009) menegaskan bahwa: Kesulitan penyusunan kebijakan publik terjadi karena beberapa penyebab yaitu penyusun kebijakan memerlukan informasi yang cukup, adanya perbedaan kepentingan, banyak aktor atau lembaga yang terlibat, pengesahan memerlukan lobby atau bargaining. Dror (1971: 12) menegaskan bahwa Pembuatan kebijakan publik: A very complex, dynamic process whose various components make different contribution to it. It decides major guidelines for action directed at future, mainly by governmental organs. These guidelines formally aim at achieving what is in the public interest by the best possible means. Lindblom (dalam Winarno, 2007: 90) menegaskan bahwa: Dalam memahami proses perumusan kebijakan perlu dipahami aktoraktor yang terlibat, baik aktor yang resmi maupun tidak resmi, dipahami sifat-sifatnya, bagian atau peran apa yang mereka lakukan, wewenang atau bentuk kekuasaan yang mereka miliki, bagaimana mereka saling berhubungan serta saling mengawasi. Agar pelaksanaan tugas pokok pemerintah dan DPRD melalui tim anggaran pemerintah kota dan DPRD kota Pontianak dalam proses formulasi KUA dapat diukur dan dievaluasi maka peneliti menggunakan pendapat Supriatna. Supriatna (1997: 104) menegaskan bahwa setiap pelaksanaan tugas dan fungsi dapat dinilai dari 3 (tiga) aspek penting yaitu: Memiliki tanggung jawab yang tinggi selaku abdi Negara dan abdi masyarakat. Responsif terhadap masalah yang dihadapi masyarakat, khususnya yang membutuhkan pelayanan masyarakat dalam arti luas dan Komitmen dan konsisten terhadap nilai standar moralitas dalam menjalankan kekuasaan pemerintahan.
Berdasarkan fokus penelitian yang telah diungkapkan maka perilaku tim dan badan anggaran dalam formulasi KUA kota Pontianak hanya dilihat dari variabel pertama yaitu perilaku yang bertanggung jawab. Djohan dan Milwan (2007: 27) menyatakan bahwa: Tanggung jawab adalah norma yang menuntut kesediaan moral setiap penyelenggaran negara untuk melaksanakan tugas dan kewajibannya secara profesional dan tekat untuk terus menerus meningkatkan mutu profesionalisme, Kehati-hatian dan kecermatan dalam setiap sikap, perilaku, tindakan maupun ucapannya baik di dalam lingkungan kerjanya maupun di luar lingkungan kerja, memikul akibat resiko dan tanggung jawab yang terpaut pada kedudukan, kewenangan dan tugas yang dilaksanakan, kewajiban untuk mengakui kesalahan, kesediaan untuk memperbaiki kesalahnnya secepat mungkin dan memikul akibat dari perilaku, tindakan, keputusan dan ucapan yang salah. Tanggung jawab seperti yang dijelaskan Djohan dan Milwan bermakna luas dan mendalam. Tanggung jawab menuntut kepada setiap penyelenggaran negara untuk melaksanakan tugas dan kewajibannya secara profesional dan memiliki tekad untuk terus menerus meningkatkan mutu profesionalisme. Mereka juga wajib memiliki kehati-hatian dan kecermatan dalam setiap sikap, perilaku, tindakan maupun ucapannya, sekaligus siap mengakui kesalahan yang dilakukan, siap dan bersedia untuk memperbaiki kesalahan yang dilakukannya secepat mingkin serta siap memikul akibat dari perilaku, tindakan, keputusan dan ucapan yang salah. Bukan sebaliknya, apabila terjadi kesalahan dicari-cari atau mencari "kambing hitam".

Untuk kepentingan analisis kebijakan publik, Dye (1978) memperkenalkan model-model analisisnya ke dalam 6 model analisis kebijakan publik yang terdiri dari: "model kelembagaan, model kelompok, model elit, model rasional, model inkremental dan model system". Berdasarkan model ini maka model yang dipergunakan untuk menganalisis formulasi KUA adalah model kelompok dan model inkremental. Kedua model tersebut dipergunakan secara bersamaan untuk menganalisis proses pembahasan KUA sampai menjadi dokumennya (Pengesahannya). Berdasarkan rumusan masalah, tinjauan pustaka dan kerangka pemikiran yang telah dijelaskan, maka hipotesis kerja yang diajukan dirumuskan sebagai berikut: "Keterlambatan formulasi kebijakan umum anggaran berkaitan dengan tanggung jawab dari tim anggaran pemerintah dan badan anggaran DPRD." 


\section{METODE PENELITIAN}

Rancangan atau desain penelitian yang dipergunakan oleh peneliti menggunakan pendekatan kualitatif. Untuk memahami dan memperoleh data primer dan sekunder tentang proses formulasi KUA, peneliti mempergunakan teknik trianggulasi (Observasi partisipatif, wawancara dan studi dokumen), sedangkan penentuan informan mempergunakan teknik purposif. Mereka yang menjadi informan terdiri dari walikota Pontianak, Sekreataris daerah dan Ketua Bappeda Kota Pontianak dari unsur eksekutif dan tim anggaran. Informan berikutnya Ketua DPRD, Sekretaris DPRD, Ketua komosi B, Ketua Komisi D dan 3 orang anggota komisi D yang juga duduk sebagai anggota badan anggaran yang berasal Fraksi Golkar, Demokrat dan PKB serta yang 1 orang anggota Komisi C dari Fraksi Golkar. Mereka semua sebagai pemain dalam proses formulasi KUA, sedangkan informan yang bukan pemain terdiri dari Ketua LSM Forum Analisis Keterwakilan dan Transparansi Anggaran (FAKTA) Kalimantan Barat dan bagian persidangan DPRD Kota Pontianak. Mereka dipilih karena mereka memahami dan tahu tentang proses formulasi KUA.

\section{HASIL PENELITIAN DAN PEMBAHASAN}

Salah satu tanggung jawab penting dalam proses formulasi KUA terkait dengan penyiapan draf KUA, pembahasan dan pengesahannya yang tepat waktu. Harapan demikian belum dapat diwujudkan oleh tim anggaran dan badan anggaran. Hasil studi dokumen diperoleh informasi bahwa tim anggaran baru menyerahkan draf KUA dari pemerintah kepada DPRD pada tanggal 28 Juni 2010 (seharusnya pertengahan bulan Juni), sedangkan pengesahan KUA tahun 2011 baru dilakukan pada tanggal 30 Agustus 2010 (harusnya awal bulan Juli). Keterlambatan terjadi karena ada faktor kesengajaan yang dilatarbelakangi oleh agenda dan motif mendapatkan keuntungan materi dan non materi untuk diri dan keluarga, konstituen, rekan sejawat, lembaga DPRD dan partai pengusungnya. Faktor "kesengajaan" dari Tim anggaran terlihat dari penyerahan draf KUA yang tidak tepat waktu. Hasil wawancara dengan anggota tim anggaran diperoleh informasi bahwa hal in dilakukan supaya badan anggaran tidak memiliki waktu yang cukup untuk mengkritisi draf KUA, sehingga mereka tidak terlalu lama memberikan tekanan-tekanan kepada tim anggaran. Dalam pembahasan KUA dan RAPBD selama ini, memang seringkali terjadi perdebatan yang a lot. Hasil wawancara dengan anggota badan anggaran diperoleh informai bahwa mereka dengan sengaja tidak segera membahas draf KUA yang telah diterimanya karena mereka memiliki agenda (tujuan dan motivasi) yang masih perlu diperjuangkan, sehingga pengesahan dokumen
KUA tahun 2011 mengalami keterlambatan. Realitas demikian sebagai salah satu wujud masih lemahnya tanggung jawab dari tim anggaran dan badan anggaran. Agenda atau motif-motif tersebut antara lain: Tim anggaran berharap bahwa Draf KUA dibahas secara singkat dan cepat, tidak mempersulit tim anggaran dan melakukan tekanantekanan serta isi draf KUA tidak mengalami perubahan yang mendasar, sedangkan motif utama dari perilaku badan anggaran antara lain: Agar anggaran DPRD, usulan dana bantuan sosial, tunjangan rumah dan tunjangan komunikasi dan biaya reses disetujui oleh timanggaran. Haris (2007: 3-4) menegaskan bahwa: DPR dan DPRD masa Orde Baru dibandingkan lembaga-lembaga legislatif produk Pemilu 1999, DPRD dan DPR memang lebih hidup, berwarna dan dinamis karena tidak lagi berisi para birokrat (sipil dan militer) yang hanya bersikap yesmen saja terhadap kekuasaan. Namun demikian, terdapat kecenderungan yang kuat bahwa vested interest pribadi dan kelompok para anggota lebih menonjolkan dalam perilaku dan kinerja anggota DPRD dibandingkan aspirasi dan kepentingan publik. Berdasarkan data yang diungkapkan dihubungan dengan pendapat Haris dapat dianalisis bahwa dibalik sikap-sikap yang telah ditunjukkan oleh sebagian anggota Badan Anggaran ternyata ada maksud atau motif tersembunyi di dalamnya yaitu menjadikan pertanyaan kritis dan nada keras tersebut sebagai "amunisi" untuk menekan tim anggaran, sehingga kepentingan mereka diakomodasi dan saransarannya diperhitungkan atau untuk memuluskan vested interest pribadi dan kelompok dari sebagian anggota badan anggaran DPRD. Hasil observasi yang terkait dengan masih lemahnya aspek tanggung jawab antara lain: (1) Mereka hadir ke ruang rapat pembahasan tidak tepat waktu atau mengalami keterlambatan antara 30 menit sampai 60 menit (1 jam), (2) Dalam pembahasan draf KUA tidak ada copyannya, sehingga mayoritas peserta rapat tidak memiliki bahan draf KUA, (3) Sebagian anggota badan anggaran dan tim anggaran tidak selalu menghadiri proses pembahasan draf KUA (berkisar antara $4-10$ orang), dan (4) Beberapa kali terjadi penundaan waktu pembahasan draf KUA yang dilakukan oleh badan anggaran.

Hersey dan Balnchard (1995:16) menyatakan bahwa: Untuk memahami atau memperkirakan perilaku manusia dapat tercermin atau terlihat melalui aktivitas-aktivitasnya, perlu diketahui motif atau kebutuhan seseorang, yang menimbulkan suatu aktivitas, sedangkan motif adalah ikhwal "mengapanya perilaku. Selanjutnya, Hersey dan Balnchard (1995:16) berpendapat bahwa "motif dianggap sebagai kebutuhan, keinginan, dorongan atau gerak hati dalam diri seseorang. Menurut esensinya, motif merupakan dorongan utama aktivitas manusia". Berdasarkan data yang telah 
diungkapkan dihubungkan dengan beberapa pendapat ahli yang telah diungkapkan dapat dianalisis bahwa perilaku tim dan badan anggaran dalam proses pembahasan formulasi KUA menimbulkan fenomena keterlambatan, pembahasan yang alot, pertanyaan-pertanyaan kritis dan penundaan pembahasan karena dilatarbelakangi oleh agenda tertentu dan motif mendapatkan keuntungan materi maupun non materi seperti mereka ingin tetap terpilih menjadi DPRD, biaya investasi waktu pemilihan legislatif dapat kembali dan bahkan bisa mendapatkan "amunisi" baru untuk modal dalam pemilu 2014. Selain itu, keuntungan materi untuk diri dan keluarga terlihat dari gaji dan tunjangan yang mereka terima setiap bulan sebesar Rp. 14 - 18 juta rupiah/bulan serta 10 tunjangan DPRD lain yaitu : (1) Tunjangan jabatan, (2) Tunjangan keluarga, (3) Tunjangan beras, (4) Tunjangan perumahan, (5) Uang jasa pengabdian, (6) Belanja komunikasi, (7) Tunjangan khusus, (8) Uang paket, (9) Tunjangan Komisi dan (10) Tunjangan Badan Anggaran. Bagi mereka yang memiliki latar belakang sebagai pengusaha, juga berupaya mendapatkan proyek. Istilah yang populer dalam menggambarkan proses mendapatkan proyek sampai pelaksanaan proyek dan pembagian keuntungan diistilahkan dengan "mafia" anggaran dan proyek. Teori persekongkolan atau teori konspirasi (conspiracy theory) merupakan teoriteori yang berusaha menjelaskan bahwa penyebab tertinggi dari satu atau serangkaian peristiwa (pada umumnya peristiwa politik, sosial atau sejarah) adalah suatu rahasia, dan seringkali memperdaya, direncanakan diam-diam oleh sekelompok rahasia orang-orang atau organisasi yang sangat berkuasa atau berpengaruh http://id.wikipedia.org/wiki/ Teori perse-kongkolan. Berdasarkan data yang telah diungkapkan dan dihubungkan dengan teori persekongkolan dapat dianalisis bahwa proses formulasi KUA dalam realitas membutuhkan persekongkolan antara tim anggaran pemerintah dengan badan anggaran DPRD. Untuk itu, jawaban atas pertanyaan: mengapa pembahasan formulasi KUA mengalami keterlambatan, berlangsung alot dan sulit atau bertele-tele karena ada faktor yang harus disepakati terlebih dahulu. Usulan badan anggaran yang kadang dipersoalan oleh tim anggaran antara lain usulan anggaran DPRD, besar tunjangan dan biaya perjalanan dinas yang begitu besar, besarnya PAD dan dana bantuan sosial. Sebaliknya, jika usulan anggota DPRD melalui badan anggaran disetujui oleh eksekutif melalui tim anggaran, maka proses rapat pembahasan draf sampai menjadi dokumen KUA akan berjalan lebih lancar dan tidak memakan waktu laman dan sebaliknya.

\section{PENUTUP}

Berdasarkan hasil penelitian, pembahasan dan analisis peneliti tentang Perilaku Tim dan Badan Anggaran Dalam Formulasi Kebijakan Umum Anggaran dapat ditegaskan bahwa keterlambatan formulasi Kebijakan Umum Anggaran Kota Pontianak Tahun 2011 disebabkan oleh lemahnya tanggung jawab dari tim anggaran pemerintah kota dan badan anggaran DPRD kota Pontianak. Keterlambatan yang terjadi karena ada faktor kesengajaan dan dimotivasi untuk mendapatkan keuntungan materi maupun non materi, untuk diri dan keluarga, kolega, dan lembaganya. Oleh karena itu, hipotesis kerja yang berbunyi: "Keterlambatan formulasi kebijakan umum anggaran berkaitan dengan tanggung jawab dari tim anggaran pemerintah dan badan anggaran DPRD", dapat diterima.

\section{DAFTAR PUSTAKA}

Alex MA. 2005. Kamus Ilmiah Populer Kontemporer. Surabaya: Karya Harapan.

Cheltenham, UK dan Northmaptom, USA: Edward Elgar.

Cozby, Paul C., 2009. Methods in Behavioral Reserarch, Terjemahan, Yogyakarta: Pustaka Pelajar.

Dye, Thomas R., 1998. Understanding Public Policy, Englewood Cliffs, New Jersey: Prentice Hall.

Dunn. Willian. 2000. Pengantar Analisis kebijakan Publik. Edisi Kedua, Jogyakarta: Gadjah Mada University Press.

Dwiyanto, Agus. 2006., Mewujudkan Good Governance Melalui Pelayanan Publik, Yogyakarta: Gadjah Mada University Press.

Haris, Syamsuddin., 2007. Partai Dan Parlemen Lokal Era Transisi Demokrasi di Indonesia, Jakarta, LIPI Press

Irawan, Andi. Perilaku rent seeking., http:// antikorupsi. org/indo/ content/view/13251/7/

Jones, Charles, O. 1996. Pengantar Kebijakan Publik, Jakarta: Remaja Grafindo Persada.

Marcol, Goktug. 2007. Hand Book of Decision Making, USA: Penn State University, Harrisburg Vennsylvania, CRC Press in an imprint of Taylor \& Francis Group, an informa Business. 
Bima Sujendara, Ngusmanto, Perilaku Tim Dan Badan Anggaran Dalam Formulasi Kebijakan Umum Anggaran 168

Mariana, Dede., dan Paskarina, Caroline. 2008.

Demokrasi Dan Politik Desentralisasi., Yogyakarta., Graha Ilmu

Parsons, Wayne., 2006. Public Policy, Pengantar Teori dan Praktek Analisis Kebijakan. Cetakan ke-2, Terjemahan, Jakarta: Kencana Prenada Media Group, Pasolong.

Price, Don K., 1968. The Study of Policy Content: A Framework for Choce, In Austin Ranny (Ed), Political Science and Public Policy, Chicago: Markham.

Saefullah, A., Djadja. 2009. Pemikiran Kontemporer Administrasi Publik, Perpektif Manajemen Sumber Daya Manusia Dalam Era Desentralisasi, Bandung: LP3AN FISIP UNPAD.

Supriatna, Tjahya. 1997. Birokrasi Pemberdayaan Dan Pengentasan Kemiskinan, Bandung: Humaniora Utama Press.

Teori persekongkolan atau teori konspirasi (conspiracy theory), http://id.wikipedia.org/wiki/ Teori_persekongkolan

Thoha, Miftah. 2002. Perspektif Perilaku Birokrasi. Jakarta: PT. Raja Grafindo Persada

Wahab, Abdul, Solichin. 2008. Pengantar Analisis Kebijakan Publik, Malang: UPT Pernerbitan UMM.

Wibawa, Samodra. 2004. Reformasi Administrasi, Bunga Rampai Pemikiran Administrasi Negara (Publik), Yogyakarta: Gava Media.

Winarno, Budi. 2007. Kebijakan Publik, Teori Dan Proses, Yogyakarta: Media Pressindo.

\section{Dokumen}

DPRD Kota Pontianak., 2009., Risalah Rapat Paripurna Ke 8 Masa Persidangan Ke I DPRD Kota Pontianak Tahun 2009 Dalam Acara Penyampaian Laporan Hasil Pembahasan Formal Badan Anggaran DPRD Kota Pontianak Dan Penandatanganan Nota Kesepakatan Tentang Kebijakan Umum APBD Dan PPAS Tahun Anggaran 2010, Pontianak: Sekretariat DPRD

DPRD Kota Pontianak., 2010., Risalah Rapat Paripurna Ke 17 Masa Persidangan Ke II DPRD Kota Pontianak Tahun 2010 Dalam Acara Penyampaian Laporan Hasil Pembahasan Formal Badan Anggaran DPRD Kota Pontianak Dan Penandatanganan Nota Kesepakatan Tentang Kebijakan Umum APBD Dan PPAS Tahun Anggaran 2011, Pontianak: Sekretariat DPRD

DPRD Kota Pontianak., 2010., Dokumen KUA tahun 2011 atau dokumen Risalah Rapat Paripurna Ke 17 Masa persidangan ke II DPRD Kota Pontianak, yang berisi proses pembahasan, tanggal-tanggal penyerahan dan pembahasan serta lampiran-lampiran yang terdiri dokumen KUA dan PPAS kota Pontianak tahun 2011. Himpunan Absen Rapat dan Kegiatan DPRD Kota Pontianak Bulan Juli 2010, disusun oleh Bagian Rapat dan Risalah, Sekretariat DPRD Kota Pontianak Tahun 201, Pontianak: Sekretariat DPRD

Sekretariat DPRD., 2010. Absen DPRD Kota Pontianak, Bulan Agustus 2010, Pontianak: Sekretariat DPRD

Sekretariat DPRD. Sub Bagian Risalah., 2010. Himpunan Hasil Rapat Panitia Musyawarah DPRD Kota Pontianak, Pontianak: Sekretariat DPRD 